\title{
Pengaruh Dosis Kompos Limbah Sereh Wangi dan Pupuk NPK terhadap Pertumbuhan dan Hasil Tanaman Bawang Putih (Allium sativum L.) di Dataran Tinggi Gayo Lues
}

\section{The Effect of Citronella Waste Compost and NPK Fertilizer on Growth and Yield of Garlic (Allium sativum L.) in the Gayo Lues Highlands}

\author{
Elisa Fitri ${ }^{1}$, Elly Kesumawati ${ }^{1}$, Jumini ${ }^{1}$ \\ Program Studi Agroteknologi PSDKU Gayo Lues, Fakultas Pertanian, Universitas \\ Syiah Kuala
}

\begin{abstract}
Abstrak. Penelitian ini bertujuan untuk mengetahui pengaruh dosis kompos limbah sereh wangi dan pupuk NPK serta interaksi diantara kedua perlakuan tersebut terhadap pertumbuhan dan hasil tanaman bawang putih di dataran tinggi Gayo Lues. Penelitian ini dilaksanakan dari bulan Januari sampai dengan April 2021di Kampung Beranang Kecamatan Kutapanjang Kabupaten Gayo Lues dan Laboratorium Dasar PSDKU Gayo Lues. Rancangan yang digunakan dalam penelitian ini adalah Rancangan Acak Kelompok pola faktorial 3 x 3 dengan 3 ulangan. Faktor yang diteliti adalah dosis kompos limbah sereh wangi yang terdiri dari 3 taraf yaitu kontrol, 10 ton ha ${ }^{-1}$ dan 20 ton ha ${ }^{-1}$ dan dosis pupuk NPK terdiri dari 3 taraf yaitu $400 \mathrm{~kg} \mathrm{ha}^{-1}, 600 \mathrm{~kg} \mathrm{ha}^{-1}$ dan $800 \mathrm{~kg} \mathrm{ha}$. Hasil penelitian menunjukkan bahwa kompos limbah sereh wangi berpengaruh sangat nyata terhadap jumlah siung umbi per rumpun dan diameter umbi. Pertumbuhan dan hasil tanaman bawang putih di dataran tinggi Gayo Lues yang terbaik dijumpai pada dosis kompos limbah sereh wangi 20 ton $\mathrm{ha}^{-1}$. Perlakuan dosis pupuk NPK berpengaruh sangat nyata terhadap jumlah siung umbi per rumpun dan diameter umbi. Pertumbuhan dan hasil tanaman bawang putih di dataran tinggi Gayo Lues yang terbaik dijumpai pada dosis pupuk NPK $800 \mathrm{~kg} \mathrm{ha}^{-1}$. Terdapat interaksi yang tidak nyata antara dosis kompos limbah sereh wangi dengan pupuk NPK terhadap pertumbuhan dan hasil tanaman bawang putih di dataran tinggi Gayo Lues.
\end{abstract}

Kata kunci : Kompos Limbah Sereh Wangi, Pupuk NPK, Bawang Putih.

Abstract. This study aims to determine the effect of the dose of citronella waste compost and NPK fertilizer and the interaction between the two treatments on the growth and yield of garlic plants in the Gayo Lues highlands. This research was conducted from January to April 2021 in Beranang Village, Kutapanjang District, Gayo Lues Regency and Gayo Lues PSDKU Basic Laboratory. The design used in this study was a $3 \times 3$ factorial randomized block design with 3 replications. The factors studied were the dose of citronella waste compost which consisted of 3 levels, namely control, 10 tons ha ${ }^{-1}$ and 20 tons $\mathrm{ha}^{-1}$ and the dose of NPK fertilizer consisted of 3 levels, namely $400 \mathrm{~kg} \mathrm{ha}^{-1}, 600 \mathrm{~kg} \mathrm{ha}^{-1}$ and $800 \mathrm{~kg} \mathrm{ha}^{-1}$. The results showed that citronella waste compost had a very significant effect on the number of bulbs per clump and tuber diameter. The best growth and yield of garlic in the Gayo Lues highlands was found at a dose of citronella waste compost of 20 tons $\mathrm{ha}^{-1}$. The dose of NPK fertilizer had a very significant effect on the number of bulbs per clump and tuber diameter. The best growth and yield of garlic in the Gayo Lues highlands was found at a dose of $800 \mathrm{~kg} \mathrm{ha}^{-1}$ NPK fertilizer. There was no significant interaction between the dose of citronella waste compost and NPK fertilizer on the growth and yield of garlic plants in the Gayo Lues highlands.

Key words : Compost of Citronella Waste, NPK Fertilizer, Garlic.

\section{Latar Belakang}

\section{PENDAHULUAN}

Bawang putih (Allium sativum L.) merupakan tanaman hortikultura penting di Indonesia, karena memiliki nilai ekonomi yang tinggi di pasaran lokal maupun internasional. Bawang putih digunakan sebagai bumbu masakan maupun obat-obatan, dalam industri makanan umbi bawang putih dijadikan ekstrak, bubuk 
atau tepung dan diolah menjadi acar. Bawang putih mengandung zat aktif alliin dan allicin keduanya merupakan senyawa sulfur yang dapat membunuh kumankuman penyakit seperti hipertensi, diabetes, hiperkolestrolenia, antibiotika dan anti virus influenza (Majewski, 2014).

Rendahnya produktivitas bawang putih dapat di pengaruhi oleh beberapa faktor seperti, cara budidaya, kesuburan tanah dan pemupukan. Budidaya tanaman bawang putih memerlukan iklim yang sejuk dan relative kering umumnya di dataran tinggi antara 700-1.100 $\mathrm{m}$ dari permukaan laut (dpl) dengan $\mathrm{pH}$ antara 6-7 (Sarwadana dan Gunadi, 2007). Lumbu Hijau merupakan varietas unggul yang memiliki potensi produksi tinggi dan dianjurkan untuk ditanam di dataran tinggi (Rukmana, 2012). Oleh karena itu perlu dilakukan perbaikan teknologi budidaya yaitu dengan penggunaan kompos limbah sereh wangi dan pemberian pupuk NPK.

Salah satu limbah pertanian yang dapat digunakan menjadi kompos atau pupuk organik adalah sisa-sisa dari penyulingan sereh wangi. Proses penyulingan sereh wangi di Kabupaten Gayo Lues menghasilkan limbah padat yang berlimpah, limbah padat yang menumpuk ini apabila tidak diolah lebih lanjut akan mencemari lingkungan dan menghabiskan lokasi penyulingan. Salah satu usaha yang dilakukan untuk mengurangi penumpukan limbah yaitu memanfaatkannya sebagai kompos organik (Marasabessy, 2013). Kandungan hara bahan organik yang terdapat dalam kompos limbah sereh wangi adalah $\mathrm{C}, \mathrm{N}, \mathrm{P}, \mathrm{K}, \mathrm{Ca}, \mathrm{Mg}$ dan $\mathrm{SiO}_{2}$ yang dapat memperbaiki struktur tanah dengan meningkatkan kandungan bahan organik tanah dan akan meningkatkan kemampuan tanah untuk mempertahankan kandungan air tanah (Suwahyono, 2014).

Pemberian kompos limbah sereh wangi dengan dosis 10 ton $\mathrm{ha}^{-1}$ pada tanaman bawang merah memberikan hasil dan pertumbuhan terbaik pada tinggi tanaman dan bobot berangkasan kering tanaman (Munawar, 2011). Selain penggunaan kompos limbah sereh wangi, faktor lain yang mempengaruhi peningkatan produksi budidaya bawang putih yaitu pupuk NPK.

Pupuk NPK mutiara 16-16-16 merupakan pupuk majemuk yang memiliki kandungan nitrogen $16 \%$, fosfor $16 \%$ dan kalium 16\%. Dosis pupuk NPK untuk tanaman bawang putih adalah $600 \mathrm{~kg} \mathrm{ha}^{-1}$ (Sandrakirana et al., 2018). Berdasarkan permasalahan di atas, maka perlu dilakukan penelitian untuk mengetahui pengaruh antara dosis kompos limbah sereh wangi dengan pupuk NPK terhadap pertumbuhan dan hasil tanaman bawang putih di Dataran Tinggi Gayo Lues.

\section{METODE PENELITIAN}

\section{Tempat dan Waktu Penelitian}

Penelitian ini telah dilaksanakan di Kampung Beranang Kecamatan Kutapanjang Kabupaten Gayo Lues dan Laboratorium Dasar PSDKU Gayo Lues. Penelitian ini berlangsung dari bulan Januari sampai dengan April 2021.

\section{Alat dan Bahan}

Alat yang digunakan pada penelitian ini adalah pisau, gunting, cangkul, tali rafia, meteran, gembor, ember, hansprayer, penggaris, papan nama, camera, timbangan digital, jangka sorong, timbangan duduk dan alat tulis. Bahan yang digunakan dalam penelitian ini adalah daun limbah penyulingan sereh wangi 30 
kg, 1 botol EM4 ukuran 1 L, gula merah $1 \mathrm{~kg}$, air $30 \mathrm{~L}$, pupuk kandang $10 \mathrm{~kg}$, bibit tanaman bawang putih varietas Lumbu Hijau sebanyak 1.458 bibit $(2 \mathrm{~kg}$ ), NPK yang digunakan sebanyak 1,62 kg, kompos limbah sereh wangi yang digunakan sebanyak $27 \mathrm{~kg}$, insektisida Imidakloropid 5\% sebanyak 1 bungkus (100 g) dan fungisida Mankozeb 80\% sebanyak 1 bungkus (200 g).

\section{Rancangan Penelitian}

Rancangan yang digunakan dalam penelitian ini adalah Rancangan Acak Kelompok (RAK) pola faktorial 3 x 3 dengan 3 ulangan. Faktor pertama adalah dosis kompos limbah sereh wangi $(\mathrm{L})$ terdiri dari 3 taraf yaitu $\mathrm{L}_{0}=$ Kontrol, $\mathrm{L}_{1}=$ 10 ton $\mathrm{ha}^{-1}, \mathrm{~L}_{2}=20$ ton ha ${ }^{-1}$. Faktor kedua dosis pupuk NPK (N) terdiri dari 3 taraf yaitu $\mathrm{N}_{1}=400 \mathrm{~kg} \mathrm{ha}^{-1}, \mathrm{~N}_{2}=600 \mathrm{~kg} \mathrm{ha}^{-1}, \mathrm{~N}_{3}=800 \mathrm{~kg} \mathrm{ha}^{-1}$.

\section{Pelaksanaan Penelitian}

\section{Pembuatan Kompos Limbah Sereh Wangi}

Langkah-langkah pembuatan kompos yaitu menyiapkan larutan 1 L EM4, $1 \mathrm{~kg}$ gula merah dan $30 \mathrm{~L}$ air diaduk merata di dalam ember, bahan kompos limbah sereh wangi sebanyak $30 \mathrm{~kg}$ yang sudah dipotong-potong dan pupuk kandang sebanyak $10 \mathrm{~kg}$ dicampur merata. Bahan pengomposan yang sudah disiapkan disiram larutan EM4. Pencampuran dilakukan perlahan dan merata. Bahan yang sudah tercampur ditumpuk ditempat yang kering kemudian ditutup dengan terpal. Pengomposan yang baik apabila terjadi penurunan tinggi tumpukan, dipegang terasa panas, tidak berbau menyengat, tidak kering dan limbah mulai lunak.

Tumpukan limbah sereh wangi setiap 3 hari sekali dibuka dan dibalik kemudian disiram merata sampai lembab dengan larutan EM4, lalu ditutup kembali demikian seterusnya. Proses ini berlangsung selama 21 hari karena dibutuhkan waku untuk menetralisir minyak atsiri yang terkandung di dalam limbah sereh wangi. Ciri-ciri kompos yang telah matang adalah berwarna coklat kehitaman, lunak dan mudah dihancurkan, suhu tumpukan sudah mendekati suhu awal pengomposan, tidak berbau menyengat dan volume menyusut. Kompos limbah sereh wangi yang sudah matang digunakan sebanyak $27 \mathrm{~kg}$.

\section{Persiapan Lahan dan Pembuatan Bedengan}

Lahan yang digunakan untuk penelitian bawang putih dicangkul hingga bongkahan tanah menjadi gembur serta gulma dan sisa-sisa tanaman pengganggu lainnya dibersihkan dari lahan. Setelah itu dibuat plot dengan ukuran lebar $100 \mathrm{~cm}$ $\mathrm{x}$ panjang $100 \mathrm{~cm}$ dan ketinggian $30 \mathrm{~cm}$ dengan jarak antar plot $30 \mathrm{~cm}$ dan jarak antar blok $50 \mathrm{~cm}$.

\section{Persiapan Bibit}

Bibit bawang putih yang digunakan pada penelitian ini yaitu bawang putih varietas Lumbu Hijau. Bibit diperoleh dari Balai Penelitian Tanaman Sayuran Lembang Jawa Barat. Umbi bawang putih yang telah disiapkan dipisahkan siungnya, siung-siung ini digunakan sebagai bibit bawang putih dan bibit di rendam dalam fungisida Dithane M-45 dengan bahan aktif Mankozeb 80\% 10 $\mathrm{cc} / \mathrm{L}$ air selama 10 menit. Hal ini dilakukan untuk mencegah serangan patogen yang di tularkan melalui tanah atau jamur fusarium, kemudian bibit yang telah diseleksi dipotong ujungnya jika terlihat titik berwarna hijau maka bibit siap tanam. Ciri-ciri bibit yang baik adalah bibit bebas dari hama dan penyakit, pangkal batang berisi penuh dan keras, siung bernas (licin, tegar dan tidak keriput) 
dan berat siung untuk bibit 1,5-3 g. Bawang putih setelah di potong ujungnya dibiarkan dahulu selama 15 hari, setelah itu baru ditanam.

\section{Penanaman Bawang Putih}

Sebelum dilakukan penanaman tanah disiram terlebih dahulu agar mudah saat penanaman. Bibit bawang putih ditanam dengan jarak tanam $10 \mathrm{~cm}$ x $15 \mathrm{~cm}$. Penanaman dilakukan dengan memasukkan 1 bibit bawang putih ke dalam setiap lubang tanam dan 2-3 cm bagian bibit dibenamkan ke dalam tanah dengan posisi tegak lurus.

\section{Penyulaman}

Penyulaman dilakukan dalam rentang waktu satu minggu setelah tanam untuk mengganti tanaman yang tidak tumbuh atau mati.

\section{Pemupukan}

Kompos limbah sereh wangi diberikan sehari sebelum tanam dengan dosis 10 ton ha ${ }^{-1}\left(1 \mathrm{~kg} \mathrm{plot}^{-1}\right)$ dan 20 ton ha ${ }^{-1}\left(2 \mathrm{~kg}\right.$ plot $\left.^{-1}\right)$ dengan cara disebar keseluruh permukaan bedengan dan diaduk dengan tanah hingga merata. Pupuk NPK diberikan pada umur 15 HST, 35 HST dan 55 HST dengan dosis $400 \mathrm{~kg} \mathrm{ha}^{-1}$ (40 g plot $\left.^{-1}\right), 600 \mathrm{~kg} \mathrm{ha}^{-1}\left(60 \mathrm{~g} \mathrm{plot}^{-1}\right)$ dan $800 \mathrm{~kg} \mathrm{ha}^{-1}\left(80 \mathrm{~g} \mathrm{plot}^{-1}\right)$ pupuk diberikan dengan cara dibenamkan dalam larikan diantara barisan tanaman.

\section{Pemeliharaan}

\section{Penyiangan dan Pembumbunan}

Penyiangan dilakukan secara manual dengan membersihkan gulma yang ada di dalam maupun di luar bedengan, penyiangan pertama setelah tanaman berumur dua minggu, penyiangan kedua dilakukan dua minggu kemudian. Pada saat fase generatif, penyiangan tidak lagi dilakukan karena dapat mengganggu proses pembentukan dan pembesaran umbi. Sedangkan pembumbunan dilakukan untuk menutup kembali umbi dan perakaran bawang putih yang terlihat keluar sehingga dapat memperkokoh tanaman agar tidak roboh dan menghasilkan umbi yang besar.

\section{Penyiraman}

Penyiraman dilakukan setiap hari diawal penanaman dan seminggu sekali setelah tanaman tumbuh baik. Penyiraman dihentikan pada saat tanaman sudah tua menjelang panen, atau pada saat daun tanaman sudah mulai menguning.

\section{Pengendalian Hama dan Penyakit}

Pengendalian hama dan penyakit dilakukan dengan 2 cara yaitu mekanik dan kimia. Pengendalian secara mekanik dilakukan dengan cara membuang hama dan bagian tanaman yang terserang penyakit. Selanjutnya pengendalian secara kimia dilakukan dengan penyemprotan insektisida Lannate biru 40SP 250 gram dan fungisida yang digunakan adalah Dithane M-45 dengan konsentrasi $2 \mathrm{~g} \mathrm{~L}^{-1}$ air.

\section{Panen}

Pemanenan bawang putih dilakukan pada umur 112 HST. Kriteria panen yang dilakukan 50\% daun telah menguning atau kering dan tangkai batang keras, pemanenan dilakukan dengan mencabut umbi dari lubang tanam. Selanjutnya bawang putih yang telah dicabut dibersihkan dari tanah yang menempel pada akar.

\section{Analisis Data}

1. Tinggi tanaman $(\mathrm{cm})$ 
Tinggi tanaman diukur pada umur 15 dan 30 hari setelah tanam (HST) menggunakan meteran yang dimulai dari pangkal batang sampai dengan ke ujung daun tertinggi.

2. Jumlah siung umbi per rumpun

Jumlah siung umbi per rumpun dihitung setelah dilakukan panen dengan menghitung jumlah siung umbi per rumpun pada setiap tanaman sampel.

3. Diameter umbi $(\mathrm{mm})$

Pengamatan diameter umbi dilakukan setelah panen, dengan mengukur bagian tengah umbi bawang putih tanaman sampel menggunakan jangka sorong.

\section{HASIL DAN PEMBAHASAN}

\section{Pengaruh Dosis Kompos Limbah Sereh Wangi terhadap Pertumbuhan dan Hasil Tanaman Bawang Putih di Dataran Tinggi Gayo Lues}

Hasil uji $\mathrm{F}$ menunjukkan bahwa kompos limbah sereh wangi berpengaruh sangat nyata terhadap jumlah siung umbi per rumpun dan diameter umbi serta berpengaruh tidak nyata pada tinggi tanaman umur 15 dan 30 HST dapat dilihat pada tabel 1.

Tabel 1. Rata-rata parameter pertumbuhan dan hasil tanaman bawang putih di dataran tinggi Gayo Lues akibat perlakuan dosis kompos limbah sereh wangi

\begin{tabular}{|c|c|c|c|c|c|}
\hline \multirow{2}{*}{\multicolumn{2}{|c|}{ Parameter }} & \multicolumn{3}{|c|}{$\begin{array}{c}\text { Dosis kompos limbah sereh } \\
\text { wangi }\left(\text { ton } \mathrm{h}^{-1}\right)\end{array}$} & \multirow{2}{*}{$\begin{array}{c}\mathrm{BNT} \\
0,05\end{array}$} \\
\hline & & $\begin{array}{c}\mathrm{L}_{0} \\
\text { (Kontrol) }\end{array}$ & $\mathrm{L}_{1}(10)$ & $\mathrm{L}_{2}(20)$ & \\
\hline \multirow{2}{*}{ Tinggi Tanaman $(\mathrm{cm})$} & $15 \mathrm{HST}$ & 21,93 & 21,21 & 22,24 & - \\
\hline & $30 \mathrm{HST}$ & 38,97 & 37,23 & 39,92 & - \\
\hline \multirow{2}{*}{\multicolumn{2}{|c|}{$\begin{array}{l}\text { Jumlah Siung Umbi per Rumpun } \\
\text { Diameter Umbi (mm) }\end{array}$}} & $3,67 \mathrm{a}$ & $8,27 \mathrm{~b}$ & $9,89 \mathrm{~b}$ & 1,80 \\
\hline & & $14,98 \mathrm{a}$ & $18,62 \mathrm{~b}$ & $21,45 \mathrm{c}$ & 2,03 \\
\hline
\end{tabular}

Keterangan: Angka yang diikuti huruf yang sama pada baris yang sama tidak berbeda nyata pada taraf $0,05 \%$ (uji $\mathrm{BNT}_{0,05}$ )

$\mathrm{L}=$ Limbah kompos sereh wangi

Tabel 1 menunjukkan bahwa pertumbuhan dan hasil bawang putih terbaik dijumpai pada dosis kompos limbah sereh wangi 20 ton ha $^{-1}$ yang berbeda nyata dengan dosis kompos limbah sereh wangi 10 ton ha ${ }^{-1}$ dan kontrol. Hal ini diduga karena pemberian pupuk organik seperti kompos limbah sereh wangi bermanfaat dalam memperbaiki struktur tanah karena terjadi penguraian bahan organik oleh organisme tanah yang mempunyai sifat perekat yang mengikat butir-butir tanah menjadi butiran lebih besar sebagai sumber zat makanan bagi tanaman, saat dilapangan curah hujan tinggi menyebabkan daun membusuk dan menguning dan mengakibatkan umbi bawang putih pecah sehingga umbi tidak lagi padat, hal ini berarti menurunkan kualitas hasil tanaman. Hal ini sesuai dengan pendapat Mujtahedi (2013) yang menjelaskan bahwa pemberian dosis kompos limbah sereh wangi mampu meningkatkan hasil umbi bawang putih walaupun kualitas nya kurang baik.

Kompos limbah sereh wangi berpengaruh tidak nyata pada tinggi tanaman pada umur 15 dan 30 HST. Hal ini diduga karena unsur hara yang terkandung 
dalam kompos limbah sereh wangi belum terserap tanaman yang disebabkan oleh faktor lingkungan sehingga tidak mempengaruhi pertumbuhan tanaman bawang putih. Hal ini sesuai dengan pendapat Syarief (2012) kompos limbah sereh wangi pada dasarnya mampu mempengaruhi tanaman bawang putih untuk proses pertumbuhan dan mampu mempengaruhi perkembangan tanaman.

Pengaruh Dosis Pupuk NPK terhadap Pertumbuhan dan Hasil Tanaman Bawang Putih di Dataran Tinggi Gayo Lues

Hasil uji F menunjukkan bahwa pupuk NPK berpengaruh sangat nyata terhadap jumlah siung umbi per rumpun dan diameter umbi serta berpengaruh tidak nyata pada tinggi tanaman umur 15 dan 30 HST dapat dilihat pada tabel 2.

Tabel 2. Rata-rata parameter pertumbuhan dan hasil tanaman bawang putih di dataran tinggi Gayo Lues akibat perlakuan dosis pupuk NPK

\begin{tabular}{|c|c|c|c|c|}
\hline \multirow[b]{2}{*}{ Parameter } & \multicolumn{3}{|c|}{ Dosis pupuk NPK $\left(\mathrm{kg} \mathrm{h}^{-1}\right)$} & \multirow[b]{2}{*}{$\begin{array}{c}\text { BNT } \\
0,05\end{array}$} \\
\hline & $\mathrm{N}_{1}(400)$ & $\mathrm{N}_{2}(600)$ & $\begin{array}{c}\mathrm{N}_{3} \\
(800)\end{array}$ & \\
\hline Tanaman & 22,80 & 20,56 & 22,02 & - \\
\hline$(\mathrm{cm}) \quad 30 \mathrm{HST}$ & 38,31 & 38,38 & 39,42 & - \\
\hline Jumlah Siung Umbi per Rumpun & $5,51 \mathrm{a}$ & $7,62 \mathrm{~b}$ & $8,69 \mathrm{~b}$ & 1,80 \\
\hline Diameter Umbi (mm) & $15,74 \mathrm{a}$ & $18,53 \mathrm{~b}$ & $20,78 \mathrm{c}$ & 2,03 \\
\hline
\end{tabular}

Keterangan: Angka yang diikuti huruf yang sama pada baris yang sama tidak berbeda nyata pada taraf $0,05 \%$ (uji $\mathrm{BNT}_{0,05}$ )

$\mathrm{N}=$ Pupuk NPK

Tabel 2 menunjukkan bahwa pertumbuhan dan hasil bawang putih terbaik dijumpai pada dosis pupuk NPK $800 \mathrm{~kg} \mathrm{~h}^{-1}$ yang berbeda nyata dengan dosis pupuk NPK $600 \mathrm{~kg} \mathrm{~h}^{-1}$ dan $400 \mathrm{~kg} \mathrm{~h}^{-1}$. Hal ini diduga karena unsur hara yang terkandung dalam pupuk NPK mampu memenuhi kebutuhan hara untuk pertumbuhan dan perkembangan hasil tanaman bawang putih walaupun hasil umbi yang dihasilkan tidak maksimal. Hal ini sesuai dengan pendapat Wahyudi et al. (2014) pemberian pupuk NPK menyebabkan struktur tanah menjadi remah, sehingga memudahkan penetrasi akar tanaman, dengan demikian pupuk NPK yang diberikan dapat dimanfaatkan oleh organ tanaman.

Pupuk NPK berpengaruh tidak nyata pada tinggi tanaman bawang putih pada umur 15 dan 30 HST. Hal ini diduga karena unsur hara yang terkandung dalam pupuk NPK belum terserap tanaman yang disebabkan oleh faktor lingkungan sehingga tidak mempengaruhi pertumbuhan tanaman bawang putih. Hal ini sesuai dengan pendapat Yebirzaf et al. (2017) pupuk NPK tidak berpengaruh terhadap pertumbuhan tinggi tanaman disebabkan kurang optimalnya tanaman dalam menyerap unsur hara karena pupuk NPK merupakan jenis pupuk lambat tersedia bagi tanaman, sehingga menyebabkan pertumbuhan tanaman seragam, tinggi tanaman juga dapat dipengaruhi oleh lingkungan seperti suhu dan cuaca.

\section{KESIMPULAN}

Kompos limbah sereh wangi berpengaruh sangat nyata terhadap jumlah siung umbi per rumpun dan diameter umbi. Pertumbuhan dan hasil tanaman bawang putih yang terbaik dijumpai pada dosis kompos limbah sereh wangi 20 ton $\mathrm{ha}^{-1}$. Pupuk NPK berpengaruh sangat nyata terhadap jumlah siung umbi per rumpun dan diameter umbi. Hasil tanaman bawang putih yang terbaik dijumpai 
pada dosis pupuk NPK $800 \mathrm{~kg} \mathrm{ha}^{-1}$. Terdapat interaksi yang tidak nyata antara dosis kompos limbah sereh wangi dengan pupuk NPK terhadap pertumbuhan dan hasil tanaman bawang putih di dataran tinggi Gayo Lues.

\section{DAFTAR PUSTAKA}

Majewski, M. 2014. Allium sativum: Facts and myths regarding human health. Journal National Insurance Public Health. 65(1):1-8.

Marasabessy, D.A. 2013. Lemongrass as a potential waste organic materials and the effect inorganic fertilizers $(\mathrm{N}, \mathrm{P}, \mathrm{K})$ on the Growth and production of ginger (Zingiber officinale Rosc.). Jurnal Budidaya Pertanian. 14(1):31-37.

Mujtahedi, N., J.I. Masuda., M. Hiramatsu, N.T.L., Hai dan H. Okubo. 2013. Role of temperature in dormancy induction and release in one-year-old seedlings of lilium longiflour. Journal Social Horticulture Sciense. 82(1):63-68.

Munawar, P. 2011. Kesuburan Tanah dan Nutrisi Tanaman. PT Penerbit IPB Press, Bogor.

Rajiman. 2011. Aplikasi pembenah tanah dan jarak tanam di lahan pasir pantai untuk produksi bawang merah. J. Teknologi. 2:83-92.

Rukmana, R. 2012. Budidaya Bawang Putih. Kanisius, Yogyakarta.

Sandrakirana, R., L. Fauzia., E.N. Alami., L. Aisyawati., D. Rahmawati., W. Handayati., I. Susanti dan Baswarsiati. 2018. Panduan Budidaya Bawang Putih. Balai Pengkajian Teknologi Pertanian Jawa Timur, Malang.

Sarwadana, S.M dan I.G.A. Gunadi. 2007. Potensi pengembangan bawang putih (Allium sativum L.) dataran rendah varietas lokal sanur. Jurnal Agritop. 26(1):19-23.

Suwahyono, U. (2014). Cara Cepat Buat Kompos Dari Limbah. Penebar Swadaya, Jakarta.

Syarief, E.S. 2012. Kesuburan dan Pemupukan Tanah Pertanian. Pustaka Buana. Bandung.

Thomson, H. 2007. PDR for Herbal Medicine (garlic), 4thed. Montvale: Thomson Health Care Inc., pp. 345-346.

Wahyudi, A., Zulqarnida dan M. Widodo. 2014. Aplikasi pupuk organik dan anorganik dalam budidaya bawang putih varietas lumbu hijau. Prosiding Seminar Nasional Pengembangan Teknologi Pertanian Politeknik Negeri Lampung; 24 Mei 2014. 
Yebirzaf, Y., B. Negash., T. Walle., Y. Gelaye., A. Melke dan K. Yissa. 2017. Collection and Characterization of Garlic (Allium sativum L.) Gersplasm for Growth and Bulb Yield at Debre Markos Ethiopia. Journal of Horticulture and Forestry. 10(3):17-26. 